\title{
TOURIST SHOPPERS' EVALUATION OF RETAIL SERVICE: A STUDY OF CROSS-BORDER VS. INTERNATIONAL OUTSHOPPERS
}

\begin{abstract}
This paper extends the concept of customer perceived value (CPV) to the tourist outshopping context and explores the differences in antecedents and outcomes of CPV between cross-border and international outshoppers. A large-scale field survey in Hong Kong with cross-border outshoppers from Mainland China and international shoppers from four Western countries (Australia, Canada, UK and USA) shows that perceived product quality, risk and value-for-money have a stronger effect on CPV for cross-border outshoppers; and employee service quality and lifestyle congruence for international outshoppers. CPV also has a stronger positive effect on satisfaction, word-of-mouth and repeat purchase intentions for cross-border outshoppers; whereas satisfaction has a stronger positive impact on word-ofmouth and repeat purchase intentions for international outshoppers. We discuss the conceptual contribution and managerial implications of our findings for international retailers, researchers and tourism organizations.
\end{abstract}

Keywords: tourist shopping behavior, cross-border outshoppers, international outshoppers, evaluation of retail service 


\section{TOURIST SHOPPERS' EVALUATION OF RETAIL SERVICE: A STUDY OF CROSS-BORDER VS. INTERNATIONAL OUTSHOPPERS}

\section{INTRODUCTION}

Shopping is an important objective of many tourists (Huang \& Hsu, 2005; Tansuhaj, Ong, \& McCullough, 1989; Timothy \& Butler, 1995) and is considered an integral part of the overall tourist experience (Yüksel, 2004). Tourism scholars also consider shopping as a means to meet tourists' needs for leisure and relaxation (Bussey, 1987; Kattiyapornpong \& Miller, 2012; Timothy \& Butler, 1995; Tsang, Tsai, \& Leung, 2011). Hence, it is not surprising to see tourist shopping emerge as one of the fastest growing sectors of the tourism industry. For example, Hong Kong is a popular tourist destination with tourist spending as a major driver of growth in retail sales. In fact, shopping expenditure by tourists jumped by 693\%, from HK\$19,934 million in 1999 to HK\$158,131 million in 2012 (Cheung, 2013) and it accounted for about $50 \%$ of total tourism receipts in 2012 (Table 1).

$<$ Take in Table 1 about here $>$

Managers in the tourism and retail sectors find that they have to increasingly cater to tourist shoppers from neighboring and far away countries. For example, luxury brand retailers in France serve tourists from both the EU and emerging markets like China. With growing mobility of tourists and the availability of air travel, the tourism and retail sectors will have to cater to a wider group of customers. This poses challenges for tourism practitioners and policy makers as tourism and hospitality firms need to cater to different groups of tourists in order to compete successfully for market share. The tourism industry's ability to attract and satisfy shoppers from other countries depends on a clear knowledge and understanding of the expectations, perceptions and drivers of value for diverse groups of tourist shoppers. 
Tourist shopping is generally divided into cross-border and international outshopping, both of which can contribute substantially to the tourism and retail sectors (Kim, Sullivan, \& Kim, 2003). For example, Mexican cross-border outshoppers contribute about US\$3 billion annually to the economy of Texas, across the border in United States, and about two-thirds of Mexicans enter the US for the purpose of shopping (Ghaddar \& Brown, 2005). In Hong Kong, overnight Chinese Mainland tourists and Chinese day trippers spent an average of $\mathrm{HK} \$ 7,453$ and HK $\$ 2,356$ per person respectively in 2010. Shopping took up the largest share of visitor spending and a third of all retail spending in Hong Kong came from visitors. Mainland Chinese made HK\$119 billion (US\$15.2 billion) of retail purchases in 2012 while local Hong Kong residents spent HK\$287 billion. Cross-border outshopping can also be a serious economic concern for the country with a huge drainage of retail sales to its competitive neighbors across the border (Lau, Sin, \& Chan, 2005; Piron, 2001).

International outshopping refers to the buying activities of tourists in countries away from home (Tansuhaj et al., 1989), whereas cross-border outshopping refers to buying activities of tourists traveling out of their own town on same-day trips to a neighboring country for shopping (Lau et al., 2005). The shopping and buying behavior of tourists is often different from their normal pattern at home (Kent, Shock, \& Show, 1983) and is more complex due to greater differences in international market environments, national controls and higher level of risk and uncertainty (Piron, 2002). However, despite significant differences in the expectations and perceptions of cross-border and international outshoppers, few studies differentiate between these two and even use these terms interchangeably (Guo, Vasquez-Parraga, \& Wang, 2006; Guo \& Wang, 2009; Piron, 2002). As a result, there is no comprehensive framework for outshopping to guide international retailers, academic researchers and tourism bodies to identify different segments of tourist outshoppers, target the most profitable segments, and develop suitable strategies to attract these tourists. 
Unlike other tourist shopping studies (e.g., Lloyd, Yip, \& Luk, 2011; Yeung \& Yee, 2012), our conceptual model has word-of-mouth, satisfaction and repurchase intention as behavioral outcomes and we compare different types of tourist outshoppers rather than simply compare local and tourist shoppers. Specifically, we first use relevant concepts and theories from the tourism and services marketing areas, in order to develop specific hypotheses about the differences in the role of antecedents and outcomes of 'customer perceived value' (CPV) between cross-border and international outshopping contexts. We then test our hypotheses using a large-scale field study in Hong Kong, a popular destination for both cross-border and international outshoppers. Finally, we discuss the conceptual and managerial contribution of our findings, their limitations and directions for future research.

\section{CONCEPTUAL FRAMEWORK AND HYPOTHESES}

\section{International Outshopping}

Outshopping is the purchase of goods by customers outside their local shopping area (Herrmann \& Beik, 1968) whereas international outshopping extends beyond national boundaries (Clark, 1994; Dawson \& Garland, 1983). International outshoppers travel to other countries (nearby or distant) to satisfy their economic (e.g., better quality, lower price or more variety) or socio-psychological (e.g., entertainment, shopping enjoyment, egoism or status-seeking) needs (Clark, 1994; Dawson \& Garland, 1983; Tansuhaj et al., 1989). While early research in this area focused on North American outshoppers, recent studies have begun exploring this phenomenon in Europe and Asia, as shown below:

- North America: Canada (Di Matteo \& Di Matteo, 1996; Timothy \& Butler, 1995), Mexico (Castaño, Perez, \& Quintanilla, 2010; Guo et al., 2006; Guo \& Wang, 2009; Sullivan et al., 2012) and USA (Lee et al., 2009) 
- Europe: Austria (Siems \& Hammer, 2011), Croatia and Serbia (Dmitrovic \& Vida, 2007), Denmark (Bygvrå, 1998), Germany (Nijssen \& Herk, 2009; Siems \& Hammer, 2011) and Sweden (Asplund, Friberg, \& Wilander, 2007))

- Asia: Middle-east (Yavas \& Abdul-Gader, 1991), Singapore (Piron, 2002; Tansuhaj et al., 1989), Hong Kong (Hui \& Lau, 2011; Lau et al., 2005; Wang \& Chen, 2004) and China (Choi et al., 2008; Wang et al., 2010; Yeung \& Yee, 2012).

These studies adopted two broad perspectives - economic and socio-psychological. Studies that adopted the economic perspective found that differences in exchange rates, per capita income, gasoline prices and taxes affected the frequency of international outshopping (Asplund et al., 2007; Di Matteo \& Di Matteo, 1996) while others examined the impact of outshopping on the economy and the private and public sector responses to this phenomenon (Sullivan et al., 2012; Timothy \& Butler, 1995). Studies that adopted the socio-psychological perspective examined the socio-demographic characteristics of shoppers, their motivations, attitudes and purchase behavior and concluded that outshopping fulfilled secular (lower level) and psychological (higher level) needs (Guo et al., 2006). Some have tried to draw profiles of these shoppers for segmentation and targeting (Yeung \& Yee, 2012) while others explore the impact of culture and ethnocentrism on international outshopping (Nijssen \& Herk, 2009; Piron, 2002; Wang et al., 2010; Yavas \& Abdul-Gader, 1991).

\section{Cross-border Outshopping}

Unlike international outshopping, cross-border outshopping is generally explained from an economic perspective on account of geographic closeness of the two countries (implying cost and time efficiency) and thus outshopping is viewed mostly as utilitarian behavior (Piron, 2002). Others also describe cross-border outshopping as primarily 
instrumental and functional in nature and argue that cross-border outshoppers do not consider leisure and store atmosphere as important and focus on lower prices due to lower taxes or duty exemptions and a chance to buy brands unavailable in their home country as the main benefits of cross-border outshopping (Arentze, Oppewal, \& Timmermans, 2005). Crossborder outshoppers shop for daily necessities like food, beverages and groceries with mostly same-day trips that are laborious with little pleasure (Piron, 2002; Timothy \& Butler, 1995).

Recent research shows that outshoppers from developing countries like China may be driven to shop in neighboring countries not only for variety but also for greater assurance of quality (Wang, 2010; Yeung \& Yee, 2012) as the retail sector in China is characterized by low level of trust and credibility (Luk, Albaum, \& Fullgrabe, 2013). The high risk of purchasing fake products of foreign brands in the domestic market prompts many Chinese to cross the border to shop in Hong Kong (Chow, 2003; Lloyd et al., 2011). Thus, risk avoidance may explain cross-border outshopping by Chinese visitors in Hong Kong. Others show that lower prices, reliability of product quality and selection varieties are the major factors explaining the motivations of Chinese outshoppers (Yeung \& Yee, 2012). Hence, it seems that international outshopping is driven by a variety of economic, social and emotional factors, whereas cross-border outshopping may be driven mainly by economic motives.

\section{Customer Perceived Value (CPV)}

Customer perceived value (CPV) has been an important topic in marketing research to such an extent that understanding and delivering what customers really value is considered the essence of marketing strategy (Khalifa, 2004; Lloyd \& Luk, 2010; Nasution \& Mavondo, 2008; Sánchez-Fernández \& Iniesta-Bonillo, 2007; Sweeney \& Soutar, 2001). CPV has its origins in equity theory, which represents the trade-off between the costs incurred by the customers and benefits received by them (Sinha \& DeSarbo, 1998); hence it is defined as an 
overall assessment of the utility based on perceptions of benefits received and sacrifices made in purchasing and consuming products (Zeithaml, 1988).

Perceived benefits refer to what the customer "gets" (e.g. product quality, service quality, and functional performance) and perceived sacrifices refers to what the customer "gives" up, (e.g. price, effort, and perceived risk). Hence, it is not surprising to see that CPV in the shopping context is affected by brand, price and store image (Dodds, Monroe, \& Grewal, 1991; Grewal et al., 1998) and perceived risk (Sweeney, Soutar, \& Johnson, 1999). However, retail shopping is a complex experience, which includes browsing around the store, looking for merchandise, waiting to be served and interacting with store employees (Dabholkar, Thorpe, \& Rentz, 1996), which may invoke emotional responses and sensory feelings that could impact CPV (Sweeney \& Soutar, 2001).

Based on the above, CPV in the shopping context may be affected by a variety of monetary and non-monetary, rational and emotional, social and psychological factors, including product and service quality, store atmosphere (Grewal \& Baker, 1994; Grewal et al., 2003) and salesforce behavior (Dodds et al., 1991). Hence, prior research examines antecedents of CPV, including product quality, service quality, perceived risk, shop environment, lifestyle congruence, perceived effort and price (Lloyd et al., 2011).

Recent research on tourist shoppers focuses on differences between local and tourist shoppers (e.g., Lloyd et al., 2011) or identified different segments of cross-border shoppers (Yeung \& Yee, 2012), but it does not distinguish between the motivations and behaviors of different types of outshoppers. Hence, it is not clear to what extent the antecedents and outcomes of CPV are similar or different for cross-border and international outshoppers. We address this research gap with a conceptual framework by including several important antecedents and outcomes of CPV under both cross-border and international outshopping 
context and accordingly formulate specific hypotheses about the differences in the relationships among these constructs.

\section{Antecedents of Customer Perceived Value}

Perceived Product Quality (PPQ): Perceived product quality has a positive impact on product evaluations and customer satisfaction (Dodds et al., 1991), which in turn may lead to a stronger store image and higher patronage due to greater perceived functional or utilitarian benefits (Pan \& Zinkhan, 2006). For cross-border outshoppers, better quality is one of the primary reasons for buying products from other countries because they may not have access to high quality brands in their own countries (Wang et al., 2010). In contrast, international outshoppers have greater access to high quality products and brands in their own countries (Sharma, 2011); hence they may have other motivations for shopping overseas, such as shopping enjoyment and social interaction. Therefore, product quality may be a stronger driver of value for cross-border (vs. international) outshoppers. In fact, recent research also shows a significant positive effect of PPQ on CPV for cross-border tourist shoppers from Mainland China in Hong Kong (Lloyd et al., 2011). Hence, we hypothesize as follows:

H1: The positive impact of PPQ on CPV is stronger for cross-border outshoppers compared to international outshoppers.

Employee Service Quality (ESQ): Service quality is an integral part of the retail shopping experience because customers are not only concerned about the outcome of their shopping trip but also their shopping experience (McDougall \& Levesque, 2000). Hence, the attitudinal and emotional responses of service employees may not only impact customers' perception of service quality (Bitner, 1990) but the quality of interaction between customers and employees may also affect the overall customer judgments (Cronin, Brady, \& Hult, 2000). ESQ is likely to be a determinant of CPV for international outshoppers as they may not be 
familiar with the shopping culture in other countries. Hence, they evaluate their shopping experience based on their experience with the store employees in their home countries, as confirmed by the positive effect of ESQ on CPV for tourist shoppers (Lloyd et al., 2011).

Moreover, for international outshoppers, shopping may not be just a means to satisfy their economic needs by way of lower prices, greater variety and convenience; instead, shopping on overseas trips may give them emotional and social benefits such as shopping enjoyment, innovation and socialization (Jarratt, 2000). For many tourists, shopping is a form of recreation making the trip a more enjoyable and relaxing experience (Bussey, 1987) and this is particularly true for international outshoppers, who tend to be more active, recreation, and sensation seekers (Burns, Lanasa, \& Lackman, 1999). International outshoppers thus place more emphasis on enjoyable interactions with employees at local shops (Oh et al., 2004). In contrast, customer service and interaction with local employees may be less important for cross-border outshoppers due to their higher utilitarian motivation. For example, Wang (2010) found that service quality had no significant impact on Chinese shoppers' satisfaction with shopping centers in Taiwan. Therefore, we hypothesize:

H2: The positive impact of ESQ on CPV is stronger for international outshoppers compared to cross-border outshoppers.

Perceived Risk (RSK): Perceived risk is defined as the subjective expectation of a loss and it correlates with the probability of making a loss (Stone \& Grønhaug, 1993). Prior research identifies different types of risk associated with shopping, including financial, performance, time and social risk (Sweeney et al., 1999) and tracks their influence on customer perceived value (Sweeney \& Soutar, 2001). Hence, perceived risk is an important determinant of CPV as an element of the non-monetary costs of acquiring and using a good or service (Cronin et al., 1997). As argued earlier, cross-border outshoppers may be more 
concerned about product quality compared to international shoppers, due to their primarily utilitarian motivation (Wang, 2010; Yeung \& Yee, 2012), hence they may be more sensitive to perceive risk while outshopping and it may affect their perceived value to a greater extent, compared to international outshoppers. Moreover, high proliferation of fake of unsafe products in their domestic markets may also make cross-border outshoppers more sensitive to perceived economic and functional risks (Chow, 2003; Lloyd et al., 2011). Hence, as follows:

H3: The negative impact of RSK on CPV is stronger for cross-border outshoppers compared to international outshoppers.

Store Environment (ENV): Store environment refers to the physical environment of a retail store consisting of its layout, signs, symbols, and artifacts (Bitner, 1992); and it affects shoppers' perceptions of store image (Baker, Grewal, \& Parasuraman, 1994) as well as their patronage intentions (Baker et al., 2002). International outshoppers are likely to pay more attention to the store environment because of their lack of familiarity and expect it the store environment to be different in other countries, which in turn may affect the evaluation of their service experience as shown in the positive impact of store environment on CPV for tourist shoppers (Lloyd et al., 2011). In contrast, cross-border outshoppers, due to their utilitarian motivation and greater familiarity with the local shopping conditions, are likely to place less importance on the store environment and instead seek lower prices or better quality as their primary objective (Yeung \& Yee, 2012). Hence, we hypothesize as follows:

H4: The positive impact of ENV on CPV is stronger for international outshoppers compared to cross-border outshoppers.

Lifestyle Congruence (LSC): Self-congruity theory proposes that the greater the match between the value-expressive attributes of the store and the consumer's self-concept, the more likely the consumer will have a favorable attitude towards the store (Sirgy, Grewal, 
\& Mangleburg, 2000). Consumers value the prestige of those brands congruent with their self-concept and style; hence, symbolic benefits of products and services are as important as functional benefits (Keller, 1993). Prior research shows that strong store image has a positive impact on the store performance (Hartman \& Spiro, 2005), product evaluations and purchase intentions (Grewal et al., 1998), as well as perceived value and loyalty (Wang, 2010).

Recent research shows that lifestyle congruence has a positive influence on CPV for both local and tourist shoppers (Lloyd et al., 2011). However, we argue that international shoppers may attach greater importance to lifestyle congruence in their value perceptions due to their greater exposure to high quality retail formats as well as well-known brands (Sharma, 2011). In contrast, cross-border outshoppers may be more inclined towards seeking better value-for-money or good bargains rather than products or services that reinforce their current lifestyles and these differences would be reflected in their perceived value (Wang, 2010; Yeung \& Yee, 2012). Hence, we hypothesize as follows:

H5: The positive impact of LSC on CPV is stronger for international outshoppers compared to cross-border outshoppers.

Perceived Effort (EFF): Prior research shows that besides monetary costs (e.g., price) for acquiring a product or service, non-monetary costs (e.g., time and effort) are important for shoppers (Brady \& Robertson, 2001; Cronin et al., 1997). In fact, shoppers who are not priceconscious may consider non-monetary costs more important, and perceive greater value if time and effort is saved (Zeithaml, 1988). Tourist shoppers generally have other aims besides shopping (e.g., sight-seeing) so they may attach more importance to non-monetary costs to save their time and effort for other activities. Hence, it is not surprising to see a negative effect of perceived effort on CPV for tourist shoppers (Lloyd et al., 2011). 
Cross-border outshopping is more task-oriented and utilitarian in nature compared to the international outshoppers; hence cross-border shoppers are likely to associate their perceived effort with their perceived value, compared to international outshoppers who in turn are likely to shop more leisurely, look for bargains, enjoy chatting with the shop assistant and other shoppers. International outshoppers also shop for entertainment and selfgratification, with perhaps little or no budget constraints. Therefore, we hypothesize:

H6: The negative impact of EFF on CPV is stronger for cross-border outshoppers compared to international outshoppers.

Value-for-Money (VFM): 'Value-for-Money' compares the benefits with costs to arrive at the monetary aspect of CPV (Richardson, Dick, \& Jain, 1994). Outshoppers are generally concerned about getting a good bargain and value-for-money, because of the greater effort and perceived risk associated with shopping outside their own country (Piron, 2002; Wang \& Chen, 2004). Paying a lower price can also cause tourists to feel pride, excitement and a sense of accomplishment (Cox, Cox, \& Anderson, 2005). Both local and tourist shoppers show a positive influence of value-for-money on CPV (Lloyd et al., 2011).

Price is a major driver for cross-border outshopping since consumers in high tax countries would take advantage of price differentials and make their purchases elsewhere, unlike more varied objectives of the international outshoppers combining both utilitarian and hedonic motivations (Asplund et al., 2007). For example, making a cross-border outshopping trip to the United States by many Canadians can be based purely on economic motivation but it may not be true for international outshoppers from European countries (Timothy \& Butler, 1995). Similarly, many Singaporean cross-border shoppers shop in Malaysia for economic reasons, whereas tourists from India and Middle-east may not focus so much on shopping (Piron, 2002). Yeung and Yee (2012) found the economic advantage of lower price coupled 
with better product and service quality as the major motivation for cross-border outshopping by Chinese tourists. Price differentials due to high value-added tax $(\sim 17 \%)$ also encourage Chinese tourists to shop in neighboring Hong Kong and Macao (Choi et al., 2008).

H7: The positive impact of VFM on CPV is stronger for cross-border outshoppers compared to international outshoppers.

\section{Outcomes of Customer Perceived Value}

Customer Satisfaction (SAT): Many studies have examined the relationship between CPV and SAT with some showing SAT leading to CPV (e.g., Chang \& Wildt, 1994; Grewal et al., 1998) while others showed instead that CPV has a positive impact on SAT (e.g., Brady et al., 2005; Cronin et al., 2000; Tam, 2004). However, CPV is an overall cognitive response to a service experience, whereas satisfaction is an emotional response (Cronin et al., 2000), and according to cognition-affect causal ordering, cognitive responses precede emotional responses (Bagozzi, 1992). Hence, both cross-border and international outshoppers are likely to form value perceptions (cognitive response) about their shopping experience before making judgments about their satisfaction (affective or emotional response). However, as shown in prior research, cross-border outshoppers have primarily utilitarian motives compared to more diverse motives of international outshoppers (Piron, 2002; Wang, 2010); hence, we expect the impact of CPV, a cognitive construct, to be stronger for cross-border (vs. international) outshoppers. In other words, cross-border outshoppers are likely to be satisfied to a greater extent by their perceived value compared to international outshoppers.

H8: The positive effect of CPV on SAT is stronger for cross-border outshoppers compared to international outshoppers. 
Word-of-Mouth (WOM): Word-of-mouth is an informal communication among individual consumers or groups of consumers to share their evaluation of goods and services (Singh, 1988). Positive WOM includes sharing of good experience with others and making positive recommendations, whereas negative WOM involves sharing of bad experiences with others and making negative recommendations (Anderson, 1998). WOM helps shape buying behavior and relates positively with product evaluations (Swan \& Oliver, 1989).

International outshoppers make fewer shopping trips and may enjoy other activities, such as dining and sightseeing, whereas cross-border outshoppers tend to make more frequent outshopping trips. Cross-border outshoppers are also likely to have friends, family members and neighbors who live close to the border and who may make similar shopping trips. Hence, they are more likely to allow their perceived value from their outshopping experience, to influence the extent to which they would share these experiences with others. In contrast, international outshoppers may not focus too much on their shopping experience alone and instead share a wider variety of experiences with their significant others in their home countries, which may not necessarily be affected by their perceived value from outshopping. In other words, CPV would have a stronger effect on WOM for cross-border outshoppers compared to international outshoppers, as hypothesized below:

H9: The positive effect of CPV on WOM is stronger for cross-border outshoppers compared to international outshoppers.

Repeat Purchase Intentions (RPI): Prior research shows that CPV has a direct effect on behavioral intentions including word-of-mouth and repeat purchase (Grewal et al., 1998) and similar findings are reported for tourist shoppers (Lloyd et al., 2011). We argue that due to their greater frequency of outshopping compared to international outshoppers, cross-border outshoppers are more likely to be influenced by CPV when considering their repeat purchase 
intentions. In fact, international outshoppers would also be restricted by their need to travel a long distance and spend large sums of money to visit their destination country merely for shopping; hence their perceived value from shopping experience may not have such a strong impact on their repeat purchase intentions. Hence, the following hypothesis:

H10: The positive effect of CPV on RPI is stronger for cross-border outshoppers compared to international outshoppers.

Finally, prior research shows that SAT has a positive impact on behavioral intentions such as WOM and RPI (Brady et al., 2005). However, CPV is a cognitive appraisal (difference between costs and benefits) whereas satisfaction is an overall affective judgment about a customer's experience (Cronin et al., 2000). Hence, we argue that cross-border outshoppers from Mainland China (relatively less developed than Hong Kong) may attach more importance to a cognitive construct (i.e., CPV) because of their stronger utilitarian shopping motivation (Wang, 2010). In contrast, international outshoppers from Western countries (relatively more developed than Hong Kong) may not have such a strong utilitarian motivation and hence they are likely to rely more on their satisfaction from the shopping experience (Brady et al., 2005). . Hence, we hypothesize that the effects of satisfaction on WOM and ROI may be stronger for international (vs. cross-border) outshoppers.

H11: The positive effect of SAT on WOM is stronger for international outshoppers compared to cross-border outshoppers.

H12: The positive effect of SAT on RPI is stronger for international outshoppers compared to cross-border outshoppers.

$<$ Take in Figure 1 about here $>$

\section{METHODOLOGY}


We tested all our hypotheses (Figure 1) with a large-scale mall-intercept survey in Hong Kong. We chose Hong Kong because it is a popular tourism and shopping destination for tourists and shoppers from all over the world (HKTB, 2012; Wang et al., 2010; Yeung \& Yee, 2012). In this study, we focus on cross-border outshoppers from Mainland China and international outshoppers from four Western countries (Australia, Canada, UK and USA), as these five countries account for $80 \%$ tourist arrivals in Hong Kong (HKTB, 2012)

\section{Sample and Procedure}

A team of 20 experienced bilingual (Chinese and English) interviewers approached about 5000 non-local shoppers in Tsim Sha Tsui, Mongkok and Central areas of Hong Kong over a three-week period during June-July 2013 and collected 802 complete questionnaires (response rate $=16 \%$ ), with 490 cross-border and 312 international outshoppers.

The shoppers were approached after they had shopped in one of six retail categories (cosmetics, electronics, fashion, jewelry, telecom services and department stores). We screened all the participants by asking them if the main purpose of their visiting Hong Kong was shopping (tourist outshoppers) and for those from Mainland China by asking if they were going to stay overnight in Hong Kong or return to their home town on the same day (crossborder outshoppers). The major land border crossing between Hong Kong and China opens only from 6:30 am to midnight and most Mainland visitors to Hong Kong are day trippers. Table 2 summarizes the sample profile and characteristics.

$<$ Take in Table 2 about here $>$

\section{Measures and Questionnaire}

We adapted the following existing scales to measure all the variables: Perceived Product quality (PPQ), Perceived risk (RSK) and Value-for-Money (VFM) (Sweeney \& 
Soutar, 2001); Employee Service quality (ESQ) (Brady \& Cronin, 2001); Store environment (ENV) (Baker et al., 2002); Lifestyle Congruence (LSC) (Johnson, Herrmann, \& Huber, 2006); Perceived Effort (EFF) (Zeithaml, 1988); Word-of-Mouth (WOM) (Anderson, 1998); Customer perceived value (CPV), satisfaction (SAT) and repeat purchase intentions (RPI) (Lloyd et al., 2011). We used seven-point Likert-type response formats for PPQ, RSK, VFM, ESQ, ENV, LSC and EFF ( $1=$ strongly disagree to $7=$ strongly agree $)$, CPV and SAT $(1=$ Very low to $7=$ Very high $)$; and WOM and RPI ( $1=$ Very unlikely to $7=$ Very likely $)$.

All the questionnaire items were originally developed in English, then translated into Chinese, and back-translated by different bilingual graduate students unrelated to this study, to ensure an objective assessment of meaning equivalence. Two researchers fluent in both Chinese and English ensured conceptual and functional equivalence between the two versions.

\section{DATA ANALYSIS AND FINDINGS}

We followed the well-established two-step process to analyze our data by first testing our measurement model and then the structural model (Anderson \& Gerbing, 1988), using Structural Equation Modeling (SEM) approach with Maximum Likelihood Estimation (MLE) procedure on AMOS 22.0. Hence, we first conducted confirmatory factor analysis and composite reliability tests on the full sample to assess all the scales (Bagozzi \& Yi, 1988).

Measurement Model: We found a good fit for the measurement model with data from the full sample $\left(\chi^{2}=1132.46, d f=442, \chi^{2} / d f=2.56, \mathrm{RMSEA}=.053, \mathrm{SRMR}=.066, \mathrm{CFI}\right.$ $=.93)$ with all the fit-indices satisfying the cut-off values $\left(1<\chi^{2} / d f<3\right)$ suggested by Wheaton et al. (1977) and (RMSEA < .06, SRMR <.08, CFI > .95) as advised by Hu and Bentler (1999). We next divided the sample into two groups (cross-border and international outshoppers) and tested the measurement model again, which shows a better fit $\left(\chi^{2}=1956.44\right.$, $\left.d f=884, \chi^{2} / d f=2.21, \mathrm{RMSEA}=.040, \mathrm{SRMR}=.054, \mathrm{CFI}=.97\right)$ compared to the full sample. 
Reliability and Validity: All the parameter estimates $(\lambda)$ are large $(>.70)$ and greater than twice their respective standard errors, showing convergent validity; and none of the confidence intervals of the correlation coefficients for each pair of scales ( $\Phi$ estimates) includes 1.0, which shows discriminant validity (Anderson \& Gerbing, 1988). We also constrained the estimated correlation parameters among all the factors to 1.0 and the $\chi^{2}$ value for the constrained model $(2766.58, d f=552)$ is significantly higher than the unconstrained model $(1634.58, \Delta d f=110)$, providing further evidence of discriminant validity (Anderson \& Gerbing, 1988). Finally, the construct reliabilities (0.81 to 0.90) as well as the average variance extracted of each construct ( 0.53 to 0.74$)$ are higher than 0.50 as well as the greater than the square of its correlation with each other construct, hence all the constructs appear to be reliable (Bagozzi \& Yi, 1988). Table 3 shows the factor loadings and descriptives (mean and standard deviation) for all the scale items. Table 4 shows the correlation matrices for the two groups - cross-border outshoppers from Mainland China and international outshoppers.

$<$ Take in Tables 3 and 4 about here $>$

Measurement Invariance: Table 5 summarizes the sequential process by which we tested all the levels of measurement invariance. We found support for full configural, metric, and scalar invariance, suggesting similar factor structures across the two groups; hence we can compare the average scores for each item across the two groups (Steenkamp \& Baumgartner, 1998). We only found partial factor covariance invariance, however it allows comparison of correlation and regression coefficients for the two groups. We did not find support for factor variance and error variance invariance; hence the correlations among different factors are different for the two groups. However, this is not a major concern as we expect the correlations among the factors to be different. Similarly, lack of error variance invariance is not a big problem as the scale reliabilities for the two groups are quite similar 
and we use latent variable modeling, which explicitly accounts for the differences in measurement error (Steenkamp \& Baumgartner, 1998).

$<$ Take in Table 5 about here $>$

Structural Model: Next, we analyzed the structural model to test all our hypotheses, As shown in Table 6, the structural model provided a good fit to the full sample $\left(\chi^{2}=1232.58\right.$, $\left.d f=454, \chi^{2} / d f=2.71, \mathrm{RMSEA}=.045, \mathrm{SRMR}=.064, \mathrm{CFI}=.95\right)$ and most path coefficients as statistically significant and in expected directions. Specifically, PPQ $(\beta=.20)$, ESQ $(\beta$ $=.17), \operatorname{RSK}(\beta=-.18)$, and VFM $(\beta=.20)$ all have a significant $(p<.001)$ positive effect on CPV. However, $\operatorname{ENV~}(\beta=.01), \operatorname{LSC}(\beta=.04)$, and $\operatorname{EFF}(\beta=-.01)$ have no significant $(p>.10)$ effect on CPV. CPV also has a significant $(p<.001)$ impact on $\operatorname{SAT}(\beta=.44)$, WOM $(\beta=.29)$ and RPI $(\beta=.32)$ and SAT has a significant $(p<.001)$ impact on both WOM $(\beta=.24)$ and $\operatorname{RPI}(\beta=.37)$.

$<$ Take in Table 6 about here $>$

To test the differences between cross-border and international outshoppers, we constrained each link in our structural model to be equal across the two groups and calculated the $\chi^{2}$ difference with respect to the general model, to test the statistical significance of the differences between the two groups, in the strength of the influence of each independent variable on $\mathrm{CPV}$, and $\mathrm{CPV}$ on WOM. The results show a significant difference for ten out of the twelve links (Table 7). We found significant differences between cross-border and international outshoppers, in the influence of PPQ, ESQ, RSK, LSC and VFM on CPV, CPV on SAT, WOM and RPI, and SAT on WOM and RPI. Hence, we found support for all our hypotheses except H4 and H6. Next, we discuss all these findings and their implications. 


\section{RESULTS AND DISCUSSION}

In this paper, we explored the differences in the role of various antecedents and outcomes of CPV between cross-border and international outshoppers. As expected, product quality, perceived risk and value-for-money had a stronger influence on CPV for the crossborder outshoppers, suggesting that their shopping behavior is utilitarian oriented. In contrast, service quality and lifestyle congruence had a stronger influence on CPV for the international outshoppers and no difference was found in the influence of store environment and perceived effort on CPV for both groups. We explain these differences using various socio-economic, cultural, and economic reasons, which affect cross-border and tourist outshoppers in terms of how they evaluate their shopping experience and form their value perceptions.

For example, cross-border outshoppers from less-developed markets are more sensitive to tangible attributes (e.g., product quality and price) (Guo \& Wang, 2009) and are also likely to be more utilitarian (vs. hedonic) in their shopping motivations, focusing on price and product quality rather than service quality (Lim \& Ang, 2008). In fact, cross-border outshoppers from China may be particularly sensitive to product quality because of the widespread availability of fakes and poor quality products in their home markets (Staake, Thiesse, \& Fleisch, 2009). Hence, it is not surprising that cross-border outshoppers from Mainland China in our study attached greater importance to product quality, perceived risk and value-for-money compared to the international outshoppers from Western countries.

Service quality and lifestyle congruence have a stronger impact on CPV for the international outshoppers compared to the cross-border outshoppers from Mainland China. This finding also supports prior research showing that customers from developed markets may be more hedonically motivated as reflected in their higher concern about how they are served by retail salespersons (Laroche et al., 2004). In fact, with relatively more extensive 
shopping experience and exposure to better quality products compared to the shoppers from less-developed countries (Sharma, 2011), international outshoppers from developed countries may look for more intangible benefits such as service quality and a match with their lifestyles.

International outshoppers may also view outshopping as entertainment or recreation. They may enjoy interacting with the sales staff, taking in the local culture and practicing their language skills while making their purchases. In fact, research shows that the path between hedonic shopping value and approach behavior (liking, spending more time and money, returning) is stronger than the path between utilitarian shopping value and approach behavior for tourist shoppers (Yüksel, 2004). For tourists from developed countries, the quest for pleasurable shopping experience may be more significant than the acquisition of products.

We did not find a significant impact of store environment (H4), lifestyle congruence (H5) and perceived (H6) effort on CPV, which reflects the high standards of shopping malls and retailers in Hong Kong that makes both cross-border and international shoppers put less emphasis on these antecedents of CPV. Specifically, we did not find a significant difference in the impact of store environment on CPV, possibly because there are many well-known international retailer brands and franchised chains in the six retail categories we investigated and both cross-border and international outshoppers may already be familiar with these retailer brands and have the right expectations of the store layout and atmospherics. Moreover, Hong Kong is a mature consumer market with world-class shopping malls offering a high quality of store environment; hence both types of shoppers may have taken it for granted.

We also found no difference in the impact of perceived effort on CPV for the two groups of outshoppers, possibly because they may not consider their shopping effort as a sacrifice and being in less familiar setting, they may expect that some effort needs to be exerted on their part. With differences in language, culture and retail practices, both cross- 
border and international outshoppers may realize and accept spending more time and efforts to explain their needs or even search for basic products such as milk powder or medicines.

We also found that CPV had a stronger influence on SAT, WOM and RPI for crossborder (vs. international) outshoppers, whereas SAT had a stronger impact on WOM and RPI for international (vs. cross-border) outshoppers. We explain these differences based on the predominant shopping motivations (utilitarian vs. hedonic) of the two groups of outshoppers, wherein cross-border outshoppers from Mainland China (relatively less developed than Hong Kong) may have been influenced by their stronger utilitarian shopping motivation in contrast with the international outshoppers from Western countries (relatively more developed than Hong Kong) who may have been affected by their stronger hedonic shopping motivation.

In this paper, we extend CPV concept to the tourist outshopping context, by including both tangible (product quality, perceived effort, store environment, and value-for-money) and intangible (service quality, perceived risk, and lifestyle congruence) antecedents of CPV to cover both cross-border and international outshoppers. We also included several outcomes of CPV (e.g., satisfaction, word-of-mouth and repeat purchase intentions) in order to provide a more complete picture of how these different types of outshoppers use CPV to evaluate their shopping experience and how it shapes their future behavioral intentions.

\section{MANAGERIAL IMPLICATIONS}

Our findings have important managerial implications. First, we highlight the need to differentiate between cross-border and international outshoppers when developing retail and tourism promotion strategies. Second, retailers targeting cross-border outshoppers from their neighboring countries (especially less-developed ones) should ensure that their products are of good quality; they provide high value-for-money and are perceived to be less risky. Recent concerns about the quality of products manufactured in China, from toys and machinery parts 
to baby food, milk, and even life-saving medicines (Xin \& Stone, 2008) and proliferation of counterfeit products in China (Kwong et al., 2009) provides an excellent opportunity for retailers in Hong Kong to target cross-border outshoppers from Mainland China.

Retailers targeting Chinese customers should emphasize merchandise quality and not just lower prices and offer genuine products, refunds and guarantees. Tourism and retailer associations may also encourage retailers to join schemes promoting the sale of genuine products. Tourism promotion agencies targeting cross-border outshoppers may also stress the quality, good value and brand authenticity of products carried by the country's retailers and the mark of quality awarded to these retailers. The tourism board could also monitor the performance of local retailers by conducting surveys (e.g., in the airport departure hall).

Retailers located close to the border and those that are frequented by cross-border outshoppers could also capitalize on the greater tendency of these outshoppers to indulge in WOM through promotions like affinity and referral programs and group discounts. In contrast, our findings show that retailers targeting international outshoppers (especially from developed countries) may find it useful to improve the intangible aspects such as service quality and offer brands that match the lifestyles of their target outshoppers. These retailers should also train their service staff in interaction skills, product knowledge, and anticipating the needs of their customers. Retailers and tourism promotion agencies may stress the quality of service tourists can expect when shopping in these stores in their advertising. Moreover, international outshoppers may rely more on their satisfaction with their shopping experience to spread positive word-of-mouth and shop again at the same retail outlet. Hence, retailers would be well advised to introduce some methods to track the satisfaction level of their international outshoppers as well as to make efforts to keep improving in this aspect. 


\section{LIMITATIONS AND FUTURE RESEARCH}

This research is one of the first efforts to explore the differences in the role of various antecedents and outcomes of CPV between cross-border and international outshoppers; however, it has certain limitations that future research may wish to address. First, we examined intentions rather than actual WOM in this study because information on actual WOM is difficult to collect in a cross-sectional study. Second, we could only study crossborder outshoppers from Mainland China, which is a developing country and as pointed out by one reviewer, Mainland Chinese cross-border outshoppers may be relatively more sensitive to the risk of purchasing fake products than others; hence our results may not be applicable to cross-border outshoppers of other countries. Moreover, we studied international outshoppers from only four countries (Australia, Canada, UK and USA), which may be inadequate for a multi-national comparison (Cadogan, 2010). Hence, future research should test our model with cross-border and international shoppers from other countries.

We used a mall-intercept approach to collect data as it is difficult to use random sampling with actual shoppers in a real-world setting, especially in a retail environment. Future research may also include other moderators such as variety-seeking tendency, valueconsciousness, prior experience, and product knowledge, which may affect the formation of $\mathrm{CPV}$ in the shopping context. Another limitation is the use of a single item measure for satisfaction. Future studies should include more items in the measure of satisfaction like satisfaction with the products purchased as well as the performance of the employees.

Prior research shows cross-cultural differences in customer expectations, perceptions, and evaluations of service encounters (Sharma, Tam, \& Kim, 2009; Zhang, Beatty, \& Walsh, 2008). Hence, it would be useful to examine the role of various personal cultural orientations on the outshopping evaluation process (Sharma, 2010). It may be useful to extend the study 
(with minor modifications) to include other settings such as restaurants and theme parks which may target cross-border and international tourists (Lord, Putrevu, \& Shi, 2008).

Finally, we need to point out that our findings can only be generalized at the group level (cross-border and international outshoppers) and not at the individual shopper's level, and to extend our findings to the individual level, it would be advisable for future research to use the same respondent to investigate whether $\mathrm{s} / \mathrm{he}$ will evaluate retail service in different ways under the cross-border versus international outshopping situation.

\section{REFERENCES}

Anderson, E. W. (1998). Customer Satisfaction and Word of Mouth. Journal of Service Research, 1(1), 5-17.

Anderson, J. C., \& Gerbing, D. W. (1988). Structural equation modeling in practice: A review and recommended two step approach. Psychological Bulletin, 103(May), 411423.

Arentze, T. A., Oppewal, H., \& Timmermans, H. J. (2005). A multipurpose shopping trip model to assess retail agglomeration effects. Journal of Marketing Research, 42(1), $109-115$.

Asplund, M., Friberg, R., \& Wilander, F. (2007). Demand and distance: Evidence on crossborder shopping. Journal of Public Economics, 91(1-2), 141-157. doi:

10.1016/j.jpubeco.2006.05.006

Bagozzi, R. P. (1992). The self-regulation of attitudes, intentions, and behavior. Social psychology quarterly, 55(2), 178-204.

Bagozzi, R. P., \& Yi, Y. (1988). On the evaluation of structural equation models. Journal of the Academy of Marketing Sciences, 16(1), 74- 84.

Baker, J., Grewal, D., \& Parasuraman, A. (1994). The influence of store environment on quality inferences and store image. Journal of the Academy of Marketing Science, $22(4), 328-339$.

Baker, J., Parasuraman, A., Grewal, D., \& Voss, G. B. (2002). The Influence of Multiple Store Environment Cues on Perceived Merchandise Value and Patronage Intentions. Journal of Marketing, 66(2), 120-141.

Bitner, M. J. (1990). Evaluating service encounters: the effects of physical surroundings and employee responses. Journal of Marketing, 52(April), 69-82. 
Bitner, M. J. (1992). Servicescapes: The Impact of Physical Surroundings on Customers and Employees. Journal of Marketing, 56(2), 57-71.

Brady, M. K., \& Cronin, J. J. J. (2001). Some new thoughts on conceptualizing perceived service quality: a hierarchical approach. Journal of Marketing, 65(3), 34-49.

Brady, M. K., Knight, G. A., Cronin, J. J. J., Hult, G. T. M., \& Keillor, B. D. (2005). Removing the Contextual Lens: A Multinational, Multi-Setting Comparison of Service Evaluation Models. Journal of Retailing, 81(3), 215-230.

Brady, M. K., \& Robertson, C. J. (2001). Searching for a consensus on the antecedent role of service quality and satisfaction: An exploratory cross-national study. Journal of Business Research, 51(1), 53-60.

Burns, D. J., Lanasa, J. M., \& Lackman, C. L. (1999). Outshopping: An examination from a motivational perspective. Journal of Professional Services Marketing, 19(2), 151-160.

Bussey, K. (1987). Leisure + Shopping = ? Leisure Management, 7(9), 22-26.

Bygvrå, S. (1998). The road to the Single European Market as seen through the Danish retail trade: Cross-border shopping between Denmark and Germany. The International Review of Retail, Distribution and Consumer Research, 8(2), 147-164.

Cadogan, J. W. (2010). Comparative, cross-cultural and cross-national research: a comment on good and bad practice. International Marketing Review, 27(6), 601-605.

Castaño, R., Perez, M. E., \& Quintanilla, C. (2010). Cross-border shopping: family narratives. Qualitative Market Research: An International Journal, 13(1), 45-57.

Chang, T.-Z., \& Wildt, A. R. (1994). Price, product information, and purchase intention: An empirical study. Journal of the Academy of Marketing Science, 22(1), 16-27.

Cheung, C. M. C. (2013). Changing landscape of Hong Kong's retail sales. http://www.statistics.gov.hk/wsc/CPS003-P4-S.pdf

Choi, T.-M., Liu, S.-C., Pang, K.-M., \& Chow, P.-S. (2008). Shopping behaviors of individual tourists from the Chinese Mainland to Hong Kong. Tourism Management, 29(4), 811-820. doi: 10.1016/j.tourman.2007.07.009

Chow, D. C. K. (2003). Organized crime, local protectionism and the trade in counterfeit goods in China. China Economic Review, 14(4), 473-478.

Clark, T. (1994). National boundaries, border zones, and marketing strategy: A conceptual framework and theoretical model of secondary boundary effects. Journal of Marketing, 58(3), 67-80.

Cox, A. D., Cox, D., \& Anderson, R. D. (2005). Reassessing the pleasures of store shopping. Journal of Business Research, 58(3), 250-259.

Cronin, J. J. J., Brady, M. K., Brand, R. R., Hightower, R. J., \& Shemwell, D. J. (1997). A cross-sectional test of the effect and conceptualization of service value. Journal of Services Marketing, 11(6), 375-391. 
Cronin, J. J. J., Brady, M. K., \& Hult, G. T. M. (2000). Assessing the effects of quality, value and customer satisfaction on consumer behavioral intentions in service environments. Journal of Retailing, 76(2).

Dabholkar, P. A., Thorpe, D. I., \& Rentz, J. O. (1996). A Measure of Service Quality for Retail Stores: Scale Development and Validation. Journal of the Academy of Marketing Science, 24(1), 3-16.

Dawson, S., \& Garland, B. (1983). An Extension of the Outshopping Paradigm to a Cross National Context. Paper presented at the AMA Educators' Conference.

Di Matteo, L., \& Di Matteo, R. (1996). An analysis of Canadian cross-border travel. Annals of Tourism Research, 23(1), 103-122.

Dmitrovic, T., \& Vida, I. (2007). An examination of cross-border shopping behaviour in South-East Europe. European Journal of Marketing, 41(3/4), 382-395.

Dodds, W. B., Monroe, K. B., \& Grewal, D. (1991). The Effects of Price, Brand, and Store Information on Buyers' Product Evaluations. Journal of Marketing Research, 28(August), 307-319.

Ghaddar, S., \& Brown, C. (2005). The cross-border Mexican shopper: a profile. Research Review, 12(2), 46-50.

Gounaris, S. P., Tzempelikos, N. A., \& Chatzipanagiotou, K. (2007). The relationships of customer-perceived value, satisfaction, loyalty and behavioral intentions. Journal of Relationship Marketing, 6(1), 63-87.

Grewal, D., \& Baker, J. (1994). Do retail store environmental factors affect consumers' price acceptability? An empirical examination. International Journal of Research in Marketing, 11(2), 107-115.

Grewal, D., Baker, J., Levy, M., \& Voss, G. B. (2003). The Effects of Wait Expectations and Store Atmosphere Evaluations on Patronage Intentions in Service-Intensive Retail Stores. Journal of Retailing, 79(4), 259-268.

Grewal, D., Krishnan, R., Baker, J., \& Borin, N. (1998). The effect of store name, brand name and price discounts on consumers' evaluations and purchase intentions. Journal of Retailing, 74(3), 331-352.

Guo, C., Vasquez-Parraga, A. Z., \& Wang, Y. J. (2006). An exploratory study of motives for Mexican nationals to shop in the US: More than meets the eye. Journal of Retailing and Consumer Services, 13(5), 351-362.

Guo, C., \& Wang, Y. J. (2009). A study of cross-border outshopping determinants: mediating effect of outshopping enjoyment. International Journal of Consumer Studies, 33(6), 644-651.

Hartman, K. B., \& Spiro, R. L. (2005). Recapturing store image in customer-based store equity: a construct conceptualization. Journal of Business Research, 58(8), 1112-1120. 
Herrmann, R. O., \& Beik, L. L. (1968). Shoppers' Movements Outside Their Local Retail Area. Journal of Marketing, 32(4), 45-51.

HKTB. (2012). Hong Kong Tourism - Fact Sheet. Hong Kong: Hong Kong Tourism Board.

Hu, L.-t., \& Bentler, P. M. (1999). Cutoff criteria for fit indexes in covariance structure analysis: conventional criteria versus new alternatives. Structural Equation Modeling, $6(1), 1-55$.

Huang, S., \& Hsu, C. H. C. (2005). Mainland Chinese residents' perceptions and motivations of visiting Hong Kong: Evidence from focus group interviews. Asia Pacific Journal of Tourism Research, 10(2), 191-205.

Hui, T. K., \& Lau, H.-F. (2011). The Behavior of Hong Kong Cross-Border Shoppers: A Nonparametric Approach. Advances in Hospitality and Leisure, 7, 89-108.

Jarratt, D. (2000). Outshopping behaviour: an explanation of behaviour by shopper segment using structural equation modelling. International Review of Retail, Distribution and Consumer Research, 10(3), 287-304.

Johnson, M. D., Herrmann, A., \& Huber, F. (2006). The Evolution of Loyalty Intentions. Journal of Marketing, 70(2), 122-132.

Kattiyapornpong, U., \& Miller, K. E. (2012). Propensity to shop: Identifying who shops till they drop. Journal of Travel \& Tourism Marketing, 29(6), 552-565.

Keller, K. L. (1993). Conceptualizing, measuring, and managing customer-based brand equity. Journal of Marketing, 57(Jan), 1-22.

Kent, W. E., Shock, P., \& Show, R. (1983). Shopping: Tourism's unsung heroine. Journal of Travel Research, 21(4), 2-4.

Khalifa, A. S. (2004). Customer value: a review of recent literature and an integrative configuration. Management Decision, 42(5), 645-666.

Kim, H. Y., Sullivan, P., \& Kim, Y. K. (2003). Concept merchandising case study: The world of shopping at The Forum Shops. Paper presented at the 12th International Conference on Research in the Distributive Trades Conference Proceedings,, Paris, France.

Kwong, K. K., Yu, W. Y. P., Leung, J. W. K., \& Wang, K. (2009). Attitude Toward Counterfeits and Ethnic Groups: Comparing Chinese and Western Consumers Purchasing Counterfeits. Journal of Euromarketing, 18(3), 157-168.

Laroche, M., Ueltschy, L. C., Abe, S., Cleveland, M., \& Yannopoulos, P. P. (2004). Service Quality Perceptions and Customer Satisfaction: Evaluating the Role of Culture. Journal of International Marketing, 12(3), 58-85.

Lau, H. F., Sin, L. Y. M., \& Chan, K. K. C. (2005). Chinese Cross-Border Shopping: An Empirical Study. Journal of Hospitality \& Tourism Research, 29(1), 110-133. 
Lee, D., Paswan, A. K., Ganesh, G., \& Xavier, M. J. (2009). Outshopping Through the Internet: A Multicountry Investigation. Journal of Global Marketing, 22(1), 53-66. doi: $10.1080 / 08911760802511410$

Lim, E. A. C., \& Ang, S. H. (2008). Hedonic vs. utilitarian consumption: A cross-cultural perspective based on cultural conditioning. Journal of Business Research, 61(3), 225232.

Lloyd, A. E., \& Luk, S. T. K. (2010). The devil wears prada or zara: A revelation into customer perceived value of luxury and mass fashion brands. Journal of Global Fashion Marketing, 1(3), 129-141.

Lloyd, A. E., Yip, L. e. S. C., \& Luk, S. T. K. (2011). An examination of the differences in retail service evaluation between domestic and tourist shoppers in Hong Kong. Tourism Management, 32(3), 520-533.

Lord, K. R., Putrevu, S., \& Shi, Y. Z. (2008). Cultural influences on cross-border vacationing. Journal of Business Research, 61(3), 183-190.

Luk, S. T. K., Albaum, G. L., \& Fullgrabe, L. (2013). Trust in customer-salesperson relationship in China's retail sector. International Journal of Retail \& Distribution Management, 41(3), 226-248.

McDougall, G. H. G., \& Levesque, T. (2000). Customer satisfaction with services: putting perceived value into the equation. Journal of Services Marketing, 14(5), 392-410.

Nasution, H. N., \& Mavondo, F. T. (2008). Organisational capabilities: antecedents and implications for customer value. European Journal of Marketing, 42(3/4), 477-501.

New Straits Times. (2013, November 2013). Shopping expenditure by tourists recorded RM18.56b in 2012, New Straits Times.

Nijssen, E. J., \& Herk, H. v. (2009). Conjoining International Marketing and Relationship Marketing: Exploring Consumers' Cross-Border Service Relationships. Journal of International Marketing, 17(1), 91-115. doi: 10.1509/jimk.17.1.91

Oh, J. Y. J., Cheng, C. K., Lehto, X. Y., \& O’Leary, J. T. (2004). Predictors of tourists' shopping behaviour: Examination of socio-demographic characteristics and trip typologies. Journal of Vacation Marketing, 10(4), 308-319.

Pan, Y., \& Zinkhan, G. M. (2006). Determinants of retail patronage: A meta-analytical perspective. Journal of Retailing, 82(3), 229-243.

Piron, F. (2001). International retail leakages: Singaporeans outshopping in Malaysia. Singapore Management Review, 23(1), 35-58.

Piron, F. (2002). International outshopping and ethnocentrism. European Journal of Marketing, 36(1/2), 189-210.

Richardson, P. S., Dick, A. S., \& Jain, A. K. (1994). Extrinsic and intrinsic cue effects on perceptions of store brand quality. Journal of Marketing, 58(4), 28-36. 
Sánchez-Fernández, R., \& Iniesta-Bonillo, M. Á. (2007). The concept of perceived value: a systematic review of the research. Marketing Theory, 7(4), 427-451.

Sharma, P. (2010). Measuring Personal Cultural Orientations: Scale Development and Validation. Journal of the Academy of Marketing Science, 38(6), 787-806.

Sharma, P. (2011). Country-of-Origin Effects in Developed vs. Emerging Markets: Exploring the Contrasting Roles of Materialism and Value-Consciousness. Journal of International Business Studies, 42(2), 285-306.

Sharma, P., Tam, J. L. M., \& Kim, N. (2009). Demystifying Intercultural Service Encounters: Toward a Comprehensive Conceptual Framework. Journal of Service Research, 12(2), 227-242.

Siems, F., \& Hammer, M. (2011). The European price corridor between Salzburg (Austria) and Freilassing (Germany): theory and empirical results. European Journal of Management, 11(2), 9-17.

Singapore Tourism Board. (2013). Singapore Tourism Board Annual Report 2012/13. Singapore: Singapore Tourism Board.

Singh, J. (1988). Consumer Complaint Intentions and Behavior: Definitional and Taxonomical Issues. Journal of Marketing, 52(January 1988), 93-107.

Sinha, I., \& DeSarbo, W. S. (1998). An integrated approach toward the spatial modeling of perceived customer value. Journal of Marketing Research, 35(2), 236-249.

Sirgy, M. J., Grewal, D., \& Mangleburg, T. (2000). Retail environment, self-congruity, and retail patronage: An integrative model and a research agenda. Journal of Business Research, 49(2), 127-138.

Staake, T., Thiesse, F., \& Fleisch, E. (2009). The emergence of counterfeit trade: a literature review. European Journal of Marketing, 43(3/4), 320-349.

Steenkamp, J.-B. E. M., \& Baumgartner, H. (1998). Assessing Measurement Invariance in Cross-National Consumer Research. Journal of Consumer Research, 25(1), 78-90.

Stone, R. N., \& Grønhaug, K. (1993). Perceived risk: further considerations for the marketing discipline. European Journal of Marketing, 27(3), 39-50.

Sullivan, P., Bonn, M. A., Bhardwaj, V., \& DuPont, A. (2012). Mexican national crossborder shopping: Exploration of retail tourism. Journal of Retailing and Consumer Services, 19(6), 596-604. doi: 10.1016/j.jretconser.2012.07.005

Swan, J. E., \& Oliver, R. L. (1989). Postpurchase Communications By Consumers. Journal of Retailing, 65(4), 516-533.

Sweeney, J. C., \& Soutar, G. N. (2001). Consumer perceived value: The development of a multiple item scale. Journal of Retailing, 77(2), 203-220. 
Sweeney, J. C., Soutar, G. N., \& Johnson, L. W. (1999). The role of perceived risk in the quality-value relationship: A study in a retail environment. Journal of Retailing, 75(1), $77-105$.

Tam, J. L. M. (2004). Customer satisfaction, service quality and perceived value: an integrative model. Journal of Marketing Management, 20(7-8), 897-917.

Tansuhaj, P., Ong, W., \& McCullough, J. (1989). International outshoppers: What are they like. Singapore Marketing Review, 4, 93-97.

Timothy, D. J., \& Butler, R. W. (1995). Cross-boder shopping: A North American perspective. Annals of Tourism Research, 22(1), 16-34. doi: 10.1016/01607383(94)00052-t

Tsang, N. K. F., Tsai, H., \& Leung, F. (2011). A critical investigation of the bargaining behavior of tourists: The case of Hong Kong open-air markets. Journal of Travel \& Tourism Marketing, 28(1), 27-47.

Wang, C.-Y. (2010). Service quality, perceived value, corporate image, and customer loyalty in the context of varying levels of switching costs. Psychology and Marketing, 27(3), 252-262. doi: 10.1002/mar.20330

Wang, C. L., \& Chen, Z. X. (2004). Consumer ethnocentrism and willingness to buy domestic products in a developing country setting: testing moderating effects. Journal of Consumer Marketing, 21(6), 391-400.

Wang, Y. J., Doss, S. K., Guo, C., \& Li, W. (2010). An investigation of Chinese consumers' outshopping motives from a culture perspective: Implications for retail and distribution. Internatial Journal of Retail \& Distribution Management, 38(6), 423-442.

Wheaton, B., Muthen, B., Alwin, D. F., \& Summers, G. F. (1977). Assessing reliability and stability in panel models. In H. D. R. (Ed.), Sociological methodology (pp. 84-136). San Francisco: Jossey-Bass.

Xin, H., \& Stone, R. (2008). Tainted Milk Scandal: Chinese Probe Unmasks High-Tech Adulteration With Melamine. Science, 322(5906), 1310-1311.

Yavas, U., \& Abdul-Gader, A. (1991). Trans-border outshopping: an Arabian Gulf study. International Review of Retail, Distribution and Consumer Research, 1(4), 455-468.

Yeung, R. M. W., \& Yee, W. M. S. (2012). A profile of the mainland Chinese cross-border shoppers: Cluster and discriminant analysis. Tourism Management Perspectives, 4(0), 106-112. doi: 10.1016/j.tmp.2012.06.001

Yüksel, A. (2004). Shopping experience evaluation: a case of domestic and international visitors. Tourism Management, 25(6), 751-759.

Zeithaml, V. A. (1988). Consumer Perceptions of Price, Quality and Value: A Means End Model and Synthesis of Evidence. Journal of Marketing, 52, 35-48.

Zhang, J., Beatty, S. E., \& Walsh, G. (2008). Review and future directions of cross-cultural consumer services research. Journal of Business Research, 61(3), 179-182. 
Figure 1 - Conceptual Framework

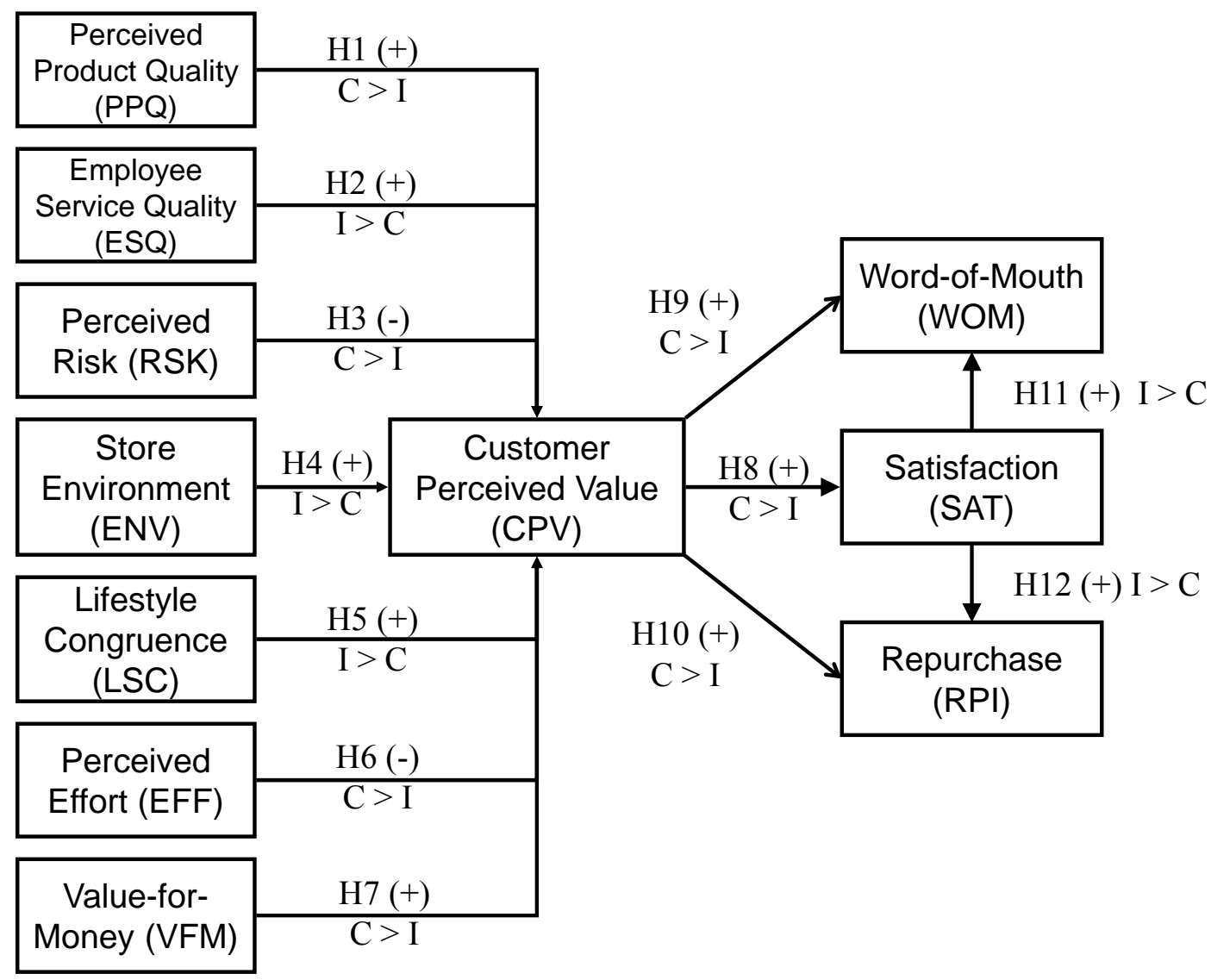


Table 1-Tourist shopping expenditure in Hong Kong, Malaysia \& Singapore (2010-2012)

\begin{tabular}{llll}
\hline Country & \multicolumn{2}{c}{2010} & \multicolumn{2}{c}{2011} & 2012 (\% of total tourism receipts) \\
\hline Hong Kong & HK\$109.6 million & HK\$133.6 million & HK\$158.1 million (55\%) \\
Malaysia & RM 16.21 billion & RM 17.5 billion & RM 18.56 billion (30.7\%) \\
Singapore & S\$4.0 billion & S $\$ 4.5$ billion & S $\$ 4.8$ billion* (21\%) \\
\hline
\end{tabular}

* Estimated

Source: Cheung (2013), New Straits Times (2013), (Singapore Tourism Board (2013)). 
Table 2 - Sample Composition (Demographics)

\begin{tabular}{|c|c|c|c|c|c|c|}
\hline Category & $\begin{array}{c}\text { Total } \\
(\mathbf{N}=\mathbf{8 0 2})\end{array}$ & $\%$ & $\begin{array}{c}\text { International } \\
\text { Outshoppers } \\
\quad(\mathbf{N}=\mathbf{3 1 2})\end{array}$ & $\%$ & $\begin{array}{c}\text { Cross-border } \\
\text { Outshoppers } \\
(\mathbf{N}=\mathbf{4 9 0})\end{array}$ & $\%$ \\
\hline \multicolumn{7}{|l|}{ Gender } \\
\hline Female & 365 & 45.5 & 133 & 42.6 & 232 & 47.3 \\
\hline Male & 437 & 54.5 & 179 & 57.4 & 258 & 52.7 \\
\hline \multicolumn{7}{|l|}{ Age } \\
\hline$\leq 20$ & 92 & 11.5 & 27 & 8.7 & 65 & 13.3 \\
\hline $21-30$ & 367 & 45.8 & 141 & 45.2 & 226 & 46.1 \\
\hline $31-40$ & 190 & 23.7 & 64 & 20.5 & 126 & 25.7 \\
\hline $41-50$ & 99 & 12.3 & 38 & 12.2 & 61 & 12.4 \\
\hline$>50$ & 54 & 6.7 & 42 & 13.5 & 12 & 2.4 \\
\hline \multicolumn{7}{|l|}{ Monthly Income } \\
\hline$\leq \mathrm{US} \$ 1250$ & 411 & 51.2 & 70 & 22.4 & 341 & 69.6 \\
\hline US\$ $1251-2500$ & 147 & 18.3 & 49 & 15.7 & 98 & 20.0 \\
\hline US\$ $2501-3750$ & 85 & 10.6 & 57 & 18.3 & 28 & 5.7 \\
\hline US\$ $3751-5000$ & 64 & 8.0 & 53 & 17.0 & 11 & 2.2 \\
\hline US\$ $5001-6250$ & 41 & 5.1 & 35 & 11.2 & 6 & 1.2 \\
\hline$>$ US\$ 6250 & 54 & 6.7 & 48 & 15.4 & 6 & 1.2 \\
\hline \multicolumn{7}{|l|}{ Education level } \\
\hline High school or below & 179 & 22.3 & 55 & 17.6 & 124 & 25.3 \\
\hline College/University & 526 & 65.6 & 203 & 65.1 & 323 & 65.9 \\
\hline Postgraduate degree & 97 & 12.1 & 54 & 17.3 & 43 & 8.8 \\
\hline
\end{tabular}


Table 3 - Scale Items (Factor Loadings \& Descriptive Statistics)

\begin{tabular}{|c|c|c|c|c|c|}
\hline \multirow[b]{2}{*}{ Scale Items } & \multicolumn{2}{|c|}{$\underline{\text { Standardized }}$} & \multicolumn{3}{|c|}{$\underline{\text { Descriptives - Mean (Std. Dev.) }}$} \\
\hline & $\begin{array}{c}\text { Inter- } \\
\text { national } \\
(\mathrm{N}=\mathbf{3 1 2})\end{array}$ & $\begin{array}{c}\text { Cross- } \\
\text { border } \\
(\mathrm{N}=\mathbf{4 9 0})\end{array}$ & $\begin{array}{c}\text { Overall } \\
(N=802)\end{array}$ & $\begin{array}{c}\text { Inter- } \\
\text { national } \\
(\mathbf{N}=\mathbf{3 1 2})\end{array}$ & $\begin{array}{c}\text { Cross- } \\
\text { border } \\
(\mathbf{N}=490)\end{array}$ \\
\hline Perceived Product Quality (PPQ) & & & $5.54(0.99)$ & $5.52(0.94)$ & $5.55(1.00)$ \\
\hline 1. Products in this store are of consistent quality & .77 & .75 & $5.51(1.28)$ & $5.38(1.30)$ & $5.55(1.27)$ \\
\hline 2. Products sold in this store perform well & .70 & .81 & $5.64(1.19)$ & $5.51(1.18)$ & $5.67(1.19)$ \\
\hline 3. Products available in this store are of good workmanship & .80 & .80 & $5.57(1.18)$ & $5.56(1.15)$ & $5.58(1.19)$ \\
\hline 4. Products in this store are of good design & .72 & .73 & $5.63(1.20)$ & $5.82(1.23)$ & $5.56(1.23)$ \\
\hline Employee Service Quality (ESQ) & & & $5.65(1.03)$ & $5.71(1.07)$ & $5.64(1.02)$ \\
\hline 1. Service employees at this store have good product knowledge & .74 & .75 & $5.66(1.23)$ & $5.55(1.27)$ & $5.69(1.21)$ \\
\hline 2. Service employees at this store are willing to help customers & .79 & .84 & $5.83(1.22)$ & $5.93(1.23)$ & $5.80(1.22)$ \\
\hline 3. Service employees at this store showed respect to me & .82 & .80 & $5.88(1.20)$ & $5.94(1.25)$ & $5.85(1.19)$ \\
\hline 4. Service employees at this store were flexible in responding to my requests & .74 & .74 & $5.60(1.26)$ & $5.67(1.24)$ & $5.58(1.26)$ \\
\hline Perceived Risk (RSK) & & & $5.93(0.99)$ & $5.81(1.12)$ & $5.97(0.94)$ \\
\hline 1. The chance of being cheated is small when shopping at this store * & .74 & .72 & $5.89(1.31)$ & $5.80(1.49)$ & $5.92(1.24)$ \\
\hline 2. The risk of paying an unfair price at this store is low $*$ & .71 & .74 & $5.75(1.31)$ & $5.53(1.58)$ & $5.82(1.19)$ \\
\hline 3. The risk of buying a fake product at this store is low $*$ & .78 & .77 & $5.90(1.32)$ & $5.66(1.65)$ & $5.98(1.17)$ \\
\hline 4. I believe it would be safe to use the products available at this store * & .73 & .80 & $5.98(1.07)$ & $6.06(1.01)$ & $5.96(1.09)$ \\
\hline 5. Billing is accurate at this store * ${ }^{*}$ & .71 & .72 & $6.11(1.09)$ & $5.99(1.22)$ & $6.15(1.05)$ \\
\hline Store Environment (ENV) & & & $5.02(1.20)$ & $4.85(1.30)$ & $5.08(1.16)$ \\
\hline 1. The layout of this store is attractive & .78 & .73 & $5.12(1.43)$ & $5.07(1.58)$ & $5.13(1.38)$ \\
\hline 2. The store is spacious & .71 & .70 & $4.76(1.62)$ & $4.26(1.80)$ & $4.92(1.53)$ \\
\hline 3. The window display at this store is attractive & .73 & .76 & $4.94(1.51)$ & $4.72(1.68)$ & $5.02(1.45)$ \\
\hline 4. The atmosphere in this store is pleasant & .74 & .77 & $5.17(1.40)$ & $5.13(1.47)$ & $5.18(1.38)$ \\
\hline 5. The display of goods at this store is attractive & .79 & .80 & $5.11(1.38)$ & $5.09(1.42)$ & $5.11(1.37)$ \\
\hline
\end{tabular}




\section{Lifestyle Congruence (LSC)}

1. The image of this store matches well with my lifestyle

2. The brands available at this store reflect my lifestyle

\section{Perceived Effort (EFF)}

1. I spent a long time searching for product(s) that interested me in this store

2. I spent too much time trying out the product(s) at this store

3. The purchase process at this store was long

4. I spent too much time explaining my needs to service employees at this store

\section{Value-for-money (VFM)}

1. Goods at this store are reasonably priced

2. Goods at this store offer value for money

\section{Customer Perceived Value (CPV)}

1. Overall, the value of the service/products offered to me at this store is...

2. Compared to what I had to give up, the overall ability of this store to satisfy my needs is..

\section{Word-of-Mouth (WOM)}

1. I will share my shopping experience about this store with others

2. I will make positive comment(s) about this store

3. I will recommend this store to others

\section{Customer satisfaction (SAT)}

1. Overall my satisfaction with the service offered at this store is...

\section{Repeat Purchase Intentions (RPI)}

1. I will plan to shop at this store when visiting Hong Kong next time.

$\begin{array}{ll}.82 & .83 \\ .83 & .89 \\ & \\ .72 & .74 \\ .77 & .76 \\ .78 & .78 \\ .73 & .79\end{array}$

83

\subsection{3 (1.35)}

$4.86(1.45)$

$5.00(1.42)$

4.96 (1.37)

$4.84(1.50)$

5.08 (1.46)

4.92 (1.34)

4.87 (1.44)

4.97 (1.41)

\subsection{8 (1.51) \\ 4.35 (1.94) \\ 4.54 (1.89) \\ $4.72(1.83)$ \\ 4.93 (1.85)}

4.98 (1.37)

$4.61(1.87)$

$5.07(1.73)$

$5.14(1.73)$

5.44 (1.60)

4.58 (1.54)

$4.27(1.96)$

4.37 (1.91)

$4.57(1.84)$

5.37 (1.18)

5.33 (1.20)

4.76 (1.90)

\subsection{4 (1.30)}

$5.40(1.23)$

$5.26(1.34)$

5.38 (1.18)

5.42(0.99)

5.22 (1.03)

\subsection{0 (1.21)}

$5.35(1.41)$

5.39 (1.27)

5.47 (1.23)

$5.25(1.53)$

$5.37(1.39)$

$5.49(1.26)$

$5.48(1.34)$

5.40 (1.19)

$5.39(1.37)$

\footnotetext{
* Reverse-scored Items.
} 
Table 4 - Correlation Matrices (Cross-border \& International Outshoppers)

\begin{tabular}{|c|c|c|c|c|c|c|c|c|c|c|c|}
\hline International Outshoppers & $P P Q$ & ESQ & RSK & ENV & LSC & EFF & VFM & $C P V$ & WOM & $S A T$ & RPI \\
\hline 1. Perceived Product Quality (PPQ) & .82 & & & & & & & & & & \\
\hline 2. Employee Service Quality (ESQ) & $.42^{* *}$ & .86 & & & & & & & & & \\
\hline 3. Perceived Risk (RSK) & $-.49^{* *}$ & $-.53^{* *}$ & .85 & & & & & & & & \\
\hline 4. Store Environment (ENV) & $.42^{* *}$ & $.43^{*}$ & $-.49^{* *}$ & .87 & & & & & & & \\
\hline 5. Lifestyle Congruence (LSC) & $.31^{* *}$ & $.23^{* *}$ & $-.29^{* *}$ & $.41^{* *}$ & .81 & & & & & & \\
\hline 6. Perceived Effort (EFF) & $.12^{*}$ & $.13^{*}$ & $-.21^{*}$ & .03 & -.02 & .84 & & & & & \\
\hline 7. Value-for-money (VFM) & $.18^{*}$ & $.27^{* *}$ & $-.26^{* *}$ & .10 & $.25^{* *}$ & .02 & .85 & & & & \\
\hline 8. Customer Perceived Value (CPV) & $.36^{* * *}$ & $.48^{* *}$ & $-.43^{* *}$ & $.34^{* *}$ & $.32^{* *}$ & .09 & $.33^{* *}$ & .83 & & & \\
\hline 9. Word-of-mouth (WOM) & $.22^{* *}$ & $.32^{* *}$ & $-.16^{* *}$ & $.29^{* *}$ & $.25^{* *}$ & -.05 & $.27^{* *}$ & $.45^{* *}$ & .90 & & \\
\hline 10. Customer Satisfaction (SAT) & $.40^{* *}$ & $.51^{* *}$ & $-.44^{* *}$ & $.37^{* *}$ & $.33^{* *}$ & $.03^{*}$ & $.27^{* *}$ & $.57^{* *}$ & $.48^{* *}$ & $N A$ & \\
\hline 11. Repeat Purchase Intentions (RPI) & $.15^{* *}$ & $.27^{* *}$ & $-.18^{* *}$ & $.27^{* *}$ & $.24^{* *}$ & -.01 & $.24^{* *}$ & $.41^{* *}$ & $.53^{* *}$ & $.41^{* *}$ & NA \\
\hline Average Variance Extracted (AVE) & .56 & .60 & .53 & .56 & .68 & .56 & .74 & .70 & .73 & NA & NA \\
\hline Cross-border Outshoppers & $P P Q$ & ESQ & RSK & ENV & LSC & EFF & VFM & $C P V$ & WOM & SAT & RPI \\
\hline 1. Perceived Product Quality (PPQ) & .86 & & & & & & & & & & \\
\hline 2. Employee Service Quality (ESQ) & $.37^{* *}$ & .86 & & & & & & & & & \\
\hline 3. Perceived Risk (RSK) & $-.61^{* *}$ & $-.55^{* *}$ & .87 & & & & & & & & \\
\hline 4. Store Environment (ENV) & $.58^{* *}$ & $.46^{* *}$ & $-.50^{* *}$ & .87 & & & & & & & \\
\hline 5. Lifestyle Congruence (LSC) & $.39^{* *}$ & $.31^{* *}$ & $-.36^{* *}$ & $.43^{* *}$ & .85 & & & & & & \\
\hline 6. Perceived Effort (EFF) & -.04 & .01 & -.05 & -.05 & $-.14^{*}$ & .87 & & & & & \\
\hline 7. Value-for-money (VFM) & $.41^{* *}$ & $.38^{* *}$ & $-.52^{* *}$ & $.32^{* *}$ & $.41^{* *}$ & -.08 & .84 & & & & \\
\hline 8. Customer Perceived Value (CPV) & $.58^{* *}$ & $.48^{* *}$ & $-.65^{* *}$ & $.43^{* *}$ & $.35^{* *}$ & -.04 & $.59^{* *}$ & .84 & & & \\
\hline 9. Word-of-mouth (WOM) & $.56^{* *}$ & $.44^{* *}$ & $-.59^{* *}$ & $.45^{* *}$ & $.37^{* *}$ & $-.11^{*}$ & $.47^{* *}$ & $.66^{* *}$ & .89 & & \\
\hline 10. Customer Satisfaction (SAT) & $.48^{* *}$ & $.54^{* *}$ & $-.63^{* *}$ & $.40^{* *}$ & $.30^{* *}$ & .03 & $.47^{* *}$ & $.72^{* *}$ & $.62^{* *}$ & $N A$ & \\
\hline 11. Repeat Purchase Intentions (RPI) & $.51^{* *}$ & $.32^{* *}$ & $-.51^{* *}$ & $.41^{* *}$ & $.37^{* *}$ & $-.09^{*}$ & $.38^{* *}$ & $.54^{* *}$ & $.57^{* *}$ & $.50^{* *}$ & $N A$ \\
\hline Average Variance Extracted (AVE) & .60 & .61 & .56 & .57 & .74 & .59 & .72 & .73 & .68 & NA & NA \\
\hline
\end{tabular}


Table 5 - Measurement Invariance - Model Comparison

\begin{tabular}{lcccccc}
\hline Model Description * & $\chi^{\mathbf{2}}$ & $\boldsymbol{d} \boldsymbol{f}$ & $\chi^{\mathbf{2}} / \boldsymbol{d} \boldsymbol{f}$ & RMSEA & SRMR & CFI \\
\hline Full configural invariance & $\mathbf{1 9 5 6 . 4 4}$ & $\mathbf{8 8 4}$ & $\mathbf{2 . 2 1}$ & $\mathbf{0 . 0 4 0}$ & $\mathbf{0 . 0 5 4}$ & $\mathbf{0 . 9 7}$ \\
Full metric invariance & $\mathbf{2 0 8 3 . 6 4}$ & $\mathbf{9 3 2}$ & $\mathbf{2 . 2 4}$ & $\mathbf{0 . 0 4 2}$ & $\mathbf{0 . 0 5 9}$ & $\mathbf{0 . 9 6}$ \\
Full scalar invariance & $\mathbf{2 2 7 7 . 0 5}$ & $\mathbf{9 9 8}$ & $\mathbf{2 . 2 8}$ & $\mathbf{0 . 0 4 5}$ & $\mathbf{0 . 0 6 1}$ & $\mathbf{0 . 9 5}$ \\
Full factor covariance invariance & $\mathbf{2 5 5 6 . 9 5}$ & $\mathbf{1 1 0 8}$ & $\mathbf{2 . 3 1}$ & $\mathbf{0 . 0 4 8}$ & $\mathbf{0 . 0 6 4}$ & $\mathbf{0 . 9 4}$ \\
Full factor error variance invariance & 2893.79 & 1139 & 2.54 & 0.054 & 0.075 & 0.91 \\
Partial factor error variance invariance & 2736.70 & 1124 & 2.43 & 0.052 & 0.068 & 0.93 \\
Full error variance invariance & 3263.51 & 1234 & 2.64 & 0.067 & 0.078 & 0.89 \\
Partial error variance invariance & 3024.43 & 1198 & 2.52 & 0.055 & 0.072 & 0.92 \\
\hline
\end{tabular}

* Rows with data in bold show the supported invariance models. 
Table 6 - Standardized Structural Equation Parameter Estimates

\begin{tabular}{|c|c|c|c|}
\hline Hypothesized Paths & $\begin{array}{c}\text { Overall } \\
\text { (Full Sample) }\end{array}$ & $\begin{array}{l}\text { International } \\
\text { Outshoppers }\end{array}$ & $\begin{array}{l}\text { Cross-border } \\
\text { Outshoppers }\end{array}$ \\
\hline H1: Perceived Product Quality $\rightarrow$ CPV & $.20 * * *$ & .09 & $.22^{* * *}$ \\
\hline H2: Employee Service Quality $\rightarrow$ CPV & $.17^{* * *}$ & $.24^{* * *}$ & $.12^{* *}$ \\
\hline H3: Perceived Risk $\rightarrow$ CPV & $-.18^{* * * *}$ & $-.10^{*}$ & $-.27^{* * *}$ \\
\hline H4: Store Environment $\rightarrow$ CPV & .01 & .04 & .00 \\
\hline H5: Lifestyle Congruence $\rightarrow$ CPV & .04 & $.09^{*}$ & -.01 \\
\hline H6: Perceived Effort $\rightarrow$ CPV & -.01 & .01 & -.02 \\
\hline H7: Value-for-money $\rightarrow$ CPV & $.20 * * *$ & $.13^{* *}$ & $.24^{* * *}$ \\
\hline $\mathrm{H} 8: \mathrm{CPV} \rightarrow \mathrm{SAT}$ & $.44^{* * *}$ & $.37^{* * *}$ & $.48^{* * *}$ \\
\hline H9: $\mathrm{CPV} \rightarrow \mathrm{WOM}$ & $.29^{* * *}$ & $.21^{* * *}$ & $.35^{* * *}$ \\
\hline H10: CPV $\rightarrow$ RPI & $.32^{* * *}$ & $.24^{* * *}$ & $.42^{* * *}$ \\
\hline H11: SAT $\rightarrow$ WOM & $.24^{* * *}$ & $.27^{* *}$ & $.16^{* * *}$ \\
\hline H12: SAT $\rightarrow$ RPI & $.37^{* * *}$ & $.43^{* * *}$ & $.29^{* * *}$ \\
\hline Chi-square value $\left(\chi^{2}\right)$ & $1232.58^{* * *}$ & \multicolumn{2}{|c|}{$1787.42^{* * *}$} \\
\hline Degrees of freedom (df) & 454 & \multicolumn{2}{|c|}{908} \\
\hline$\chi^{2} / \mathrm{df}$ & 2.71 & \multicolumn{2}{|c|}{1.97} \\
\hline CFI & .95 & \multicolumn{2}{|c|}{.97} \\
\hline NFI & .93 & \multicolumn{2}{|c|}{.95} \\
\hline IFI & .92 & \multicolumn{2}{|c|}{.93} \\
\hline TLI & .91 & \multicolumn{2}{|c|}{.92} \\
\hline RMSEA & .045 & \multicolumn{2}{|c|}{.040} \\
\hline SRMR & .064 & \multicolumn{2}{|c|}{.056} \\
\hline
\end{tabular}


Table 7 - Multi-group Moderator Analysis (Using SEM)

Unconstrained Model: $\chi_{\left({ }_{(884)}\right.}=1787.42 * * *$

\begin{tabular}{lcc}
\hline Link & $\chi^{\mathbf{2}}{ }^{(885)}$ & $\Delta \chi^{2}(\Delta \mathbf{d f}=\mathbf{1})$ \\
\hline H1: PPQ-CPV & $1792.75^{* * *}$ & $5.33^{*}$ \\
H2: ESQ-CPV & $1794.54^{* * *}$ & $7.12^{* *}$ \\
H3: RSK-CPV & $1793.28^{* * *}$ & $5.86^{*}$ \\
H4: ENV-CPV & $1789.17^{* * *}$ & 1.75 \\
H5: LSC-CPV & $1791.46^{* * *}$ & $4.04^{*}$ \\
H6: EFF-CPV & $1790.33^{* * *}$ & 2.91 \\
H7: VFM-CPV & $1793.81^{* * *}$ & $6.89^{* *}$ \\
H8: CPV-SAT & $1791.94^{* * *}$ & $4.52^{*}$ \\
H9: CPV-WOM & $1793.58^{* * *}$ & $7.16^{* *}$ \\
H10: CPV-RPI & $1792.29^{* * *}$ & $4.87^{* *}$ \\
H11: SAT-WOM & $1792.76^{* * *}$ & $5.34^{*}$ \\
H12: SAT-RPI & $1794.19^{* * *}$ & $6.77^{* *}$ \\
\hline & $p<.05,{ }^{* * *} p<.01,{ }^{* * *} p<.001$ &
\end{tabular}

